Article

\title{
Religious Inequality in America
}

\author{
Melissa J. Wilde *, Patricia Tevington and Wensong Shen \\ Department of Sociology, University of Pennsylvania, Philadelphia, PA 19104, USA; E-Mails: mwilde@sas.upenn.edu (M.J.W), \\ ptev@sas.upenn.edu (P.T), wensong@sas.upenn.edu (W.S) \\ * Corresponding author
}

Submitted: 30 January 2018 | Accepted: 24 March 2018 | Published: 22 June 2018

\begin{abstract}
Sociology has largely ignored class differences between American religious groups under the assumption that those differences "are smaller than they used to be and are getting smaller all of the time" (Pyle \& Davidson, 2014, p. 195). This article demonstrates that profound class differences remain amongst American religious groups. These differences are as large as-or larger than-commonly examined forms of inequality such as the gender pay gap and the race achievement gap. Using the most popular categorization of American religious groups, we find that regardless of the particular measure examined (years of education, income, socioeconomic index score, and proportion of members with at least a bachelor's degree) Jews and Mainline Protestants are at the top of the socioeconomic ladder and Evangelical Protestants, both black and white, are at the bottom. Furthermore, religious group significantly predicts both years of education and the overall socioeconomic standing of respondents by itself with basic controls. Likewise, both socioeconomic indicators and education significantly predict the likelihood of being in a specific religious tradition on their own with basic controls. Some religious groups, namely Evangelical Protestants at the low end and Jews and the high end, are relatively educationally homogeneous. Others, such as Catholics, Mainline Protestants and the nonreligious are much more educationally heterogeneous. In sum, religious inequality remains in America, it is robust, and it appears to be quite durable.
\end{abstract}

\section{Keywords}

class; education; inequality; race; religious tradition; social class

\section{Issue}

This article is part of the issue "Complex Religion: Intersections of Religion and Inequality", edited by Melissa J. Wilde (University of Pennsylvania, USA).

(C) 2018 by the authors; licensee Cogitatio (Lisbon, Portugal). This article is licensed under a Creative Commons Attribution 4.0 International License (CC BY).

\section{Introduction}

Until very recently, religious inequality has not been a commonly acknowledged nor researched phenomenon. Indeed, especially in regression analyses, researchers typically treat religion and class as independent factors. This article demonstrates that profound class differences remain between American religious groups that are both substantively and statistically significant. These differences are as large or larger than commonly examined forms of inequality, and appear to be just as durable (Tilly, 1999). We therefore argue that researchers should examine religion in interaction with class, rather than controlling for it, in most analyses.
This article examines current differences in both education and socioeconomic indicators for the religious categories typically used by survey researchers (RelTrad), using two of the best datasets available: the General Social Survey (GSS) and the Pew Religious Landscape Survey. We first demonstrate that, regardless of the measure or dataset, powerful class differences remain, with Jews and Mainline Protestants at the top of the socioeconomic ladder and Evangelical Protestants, both black and white, at the bottom.

These differences are as substantial as forms of inequality long acknowledged and studied by sociologists, such as the gender pay gap or the race achievement gap. For example, women today make approximately 
80 cents for every dollar that men make (Blau \& Kahn, 2006, 2016; Graf, Brown, \& Patten, 2017; Proctor, Semega, \& Kollar, 2016). In comparison, white Evangelical Protestants make only 73 cents for every dollar made by Mainline Protestants. In terms of education, white Evangelical Protestants have half the proportion of bachelor's degrees as white Mainline Protestants and a quarter of the BAs of white Jews. This is comparable to or larger than many measures of racial inequality, including the percentage of bachelor's degree by race (Kao \& Thompson, 2003; Snyder \& Dillow, 2015) and estimates of differences in standardized test scores (Fryer \& Levitt, 2004; Hedges \& Nowell, 1999; Kao \& Thompson, 2003).

To be clear, we are not implying here that the mechanisms behind religious inequality are necessarily the same as gender or racial inequality, which have long been attributed to discrimination (as well as other causes such as gender socialization and the ways in which race and class intersect). Our point here is merely that because these other forms of inequality are accepted as significant, we know more about both their causes and their consequences. In comparison, we know very little about the causes or consequences of religious inequality today. This is the case despite the fact that religious inequality is robust, so much so that both education and socioeconomic indicators significantly predict religious group membership, and religious group membership also significantly predicts both measures of class.

In reporting these findings, we are not trying to make a causal argument. Instead, we simply aim to convince sociologists that religion intersects with inequality in complex ways and that those interactions should be examined in analyses. This argument, and the findings that support it, are a result of our engagement with a growing body of work that employs theories of "complex religion" (Wilde, 2017; Wilde \& Glassman, 2016; Wilde \& Tevington, 2017).

\section{Complex Religion and the Current State of Research on Religious Inequality}

Theories of complex religion stress that religion is a core social structure that deeply overlaps with inequality in crucial ways (Wilde, 2017; Wilde \& Glassman, 2016; Wilde \& Tevington, 2017). This basic insight draws on theories of "complex inequality" which argue that inequality is complex and multidimensional (McCall, 2001). Researchers in this school urge others to examine inequalities of gender, race, or class as a combination of factors that interact with each other (Choo \& Ferree, 2010). Stressing the "multiple, overlapping, conflicting, and changing structures of inequality" (McCall, 2001, p. $14)$, these theorists argue that specific contexts of structural disadvantage lead to different outcomes and experiences. Complex religion extends this argument to religion, urging researchers to consider religion a core social structure that is highly correlated with inequality.
That religion intersects with inequality is neither a new or revolutionary claim. Classical sociologists saw the study of religion and class as core to the sociological enterprise (Baltzell, 1964; Cantril, 1943; Greeley, 1978; Niebhur, 1929; Pope, 1948; Weber, 2003). Some scholars have examined socioeconomic differences between religious traditions and denominations (Baltzell, 1964; Cantril, 1943; Davidson \& Pyle, 2011; Greeley, 1972; Niebhur, 1929; Pope, 1948; Pyle, 2006; Pyle \& Davidson, 2012, 2014; Schwadel, 2016; Sherkat, 2012; Smith \& Faris, 2005) while others have focused on stratification within these traditions (Demerath, 1965; Eagle, 2012; Reimer, 2007; Schwadel, 2009; Yancey \& Kim, 2008). This article examines both types of inequality.

Although once a common topic of classic sociological studies, the connection between socioeconomic inequality and religious traditions has waned until very recently (Keister \& Sherkat, 2014). Perhaps because it went largely uninvestigated for decades, most researchers are under the impression that religious differences "are smaller than they used to be and getting smaller all of the time" (Pyle \& Davidson, 2014, p. 195). However, a growing body of research suggests that, in one way or another, significant class differences remain between American religious groups.

With a few exceptions (notably, Davidson \& Pyle, 2011; Pyle \& Davidson, 2014; Sherkat, 2012; Shi, Massengill, \& Boddie, 2012; Smith \& Faris, 2005), very little contemporary scholarship intentionally examines the full spectrum of religious inequality. In this article, our goal is to establish that religious inequality remains in America, and that it is, perhaps surprisingly, incredibly robust. As we focus on establishing the depth and strength of religious inequality in America today, we are focusing on class, although, of course, religion intersects with aspects of inequality other than class, especially race and gender (Wilde \& Danielsen, 2014). We leave claims about how religion intersects with race or gender for future analyses where they are the focus (although we do include both race and gender in this analysis).

\subsection{What We Know about the State of Religious Inequality}

Although religious inequality has not been explicitly studied by many sociologists, it is possible to piece together some clear patterns and predictions from previous studies. Originally the subject of much early sociological thought (Weber, 2003), most accept that the differences between Catholics and Mainline Protestants have waned, but this is the case only if one does that not include recent cohorts of Catholic immigrants in the comparison (Keister, 2007).

By far the most well-documented (although, we would argue, largely ignored in terms of its implications both theoretically and methodologically) aspect of religious inequality today has to do with the lower class- 
standing of white Evangelical Protestants (Beyerlein, 2004; Darnell \& Sherkat, 1997; Fitzgerald \& Glass, 2008, 2014; Keister, 2008, 2012; Lehrer \& Chen, 2014; Massengill, 2008; McConkey, 2001; Sherkat, 1991). Typically, Evangelicals' - also known as Conservative Protestantslower class-standing is examined in comparison to Mainline Protestants, the group that historically made up the "Protestant Establishment" (Baltzell, 1964), sometimes referred to as the "gatekeepers" of American society (Coe \& Davidson, 2014; Davidson \& Pyle, 2011). Recent research demonstrates that Mainline Protestants have retained their class advantages and have been joined by Jews at the top of religious economic ladder (Keister, 2003, 2012; Sherkat, 2012).

Racial discrimination has also shaped religious inequality in the U.S. Black Protestants, who are generally seen to be theologically closest to Evangelicals (Greeley \& Hout, 2006), are largely even worse off than white Evangelicals. Because having a separate Black Protestant category makes interacting religious group with race problematic and because fully $25 \%$ of African Americans are not Black Protestants, we leave any claims about intersections of racial inequality and religion to other research (see Wilde, Pilgrim, \& Shen, 2017)especially given recent developments about how to better group African American religious groups (Shelton \& Cobb, 2017).

Finally, in terms of the major religious groups covered by RelTrad, we would be remiss to not discuss those with no religion, often referred to as "Nones". Nonreligious Americans now constitute about $20 \%$ of the American population (Hout \& Fischer, 2014; Massengill, 2014). Our analyses presented below demonstrate that Nones are as varied in class background as Mainline Protestants and Catholics, a finding that - to the best of our knowledgehas not been commonly observed in the literature.

\subsection{Causes of Religious Inequality}

Like other researchers interested in religion and inequality who explicitly eschew causal claims (Keister \& Sherkat, 2014, p.3), we are not making any causal claims about the differences we find here by employing the complex religion approach. We do not argue that these differences result from people choosing their religious affiliation based on their social class, even though there is some evidence of this (Hout \& Wilde, 2004; Schwadel, 2011; Sherkat, 1991; Solt, 2014; Wuthnow, 1988). We also do not argue that some religious subcultures encourage or discourage wealth accumulation (Keister, 2008, 2011) or class mobility, even though there is some evidence of this (Darnell \& Sherkat, 1997; Fitzgerald \& Glass, 2008, 2014; Glass \& Jacobs, 2005; Lehrer, 2004; Scheitle \& Smith, 2012; Sherkat, 2010, 2011).

While all of these are likely mechanisms behind some of the differences between American religious groups, the relatively large class differences we report here are likely mostly a result of the process of social reproduc- tion (Bourdieu, 1984; Pyle \& Davidson, 2014) set in place long ago by variations in immigration and settlement patterns over the course of American history. These immigration patterns have interacted with race, ethnicity, and variations in economic opportunity in different geographic areas in ways that disadvantage some group groups while reproducing the advantage of others (Ellis, 2015; Orsi, 2002).

For example, at the turn of the twentieth century, many elite Americans were deeply concerned with poor, uneducated Catholic and Jewish immigrants' flooding the shores of the U.S. (Wilde \& Danielsen, 2014). Today, white Catholics have assimilated into the U.S. and achieved middle class white status (Greeley, 1978). Jews have done even better, surpassing the educational attainment of the most highly educated Mainline Protestants. A key part of both groups' mobility was access to higher education (Keister, 2007), something that was likely less accessible for religious groups that settled in less urban areas outside of the Northeast, such as Evangelical Protestants (Finke \& Stark, 2005). New, more recent waves of immigrant Catholics continue to change the religious, ethnic, and class landscape. Latino immigrants, who constitute the majority of those of "other" ethnicities in the Catholic category (Pew Research Center, 2015) are much less educated and have less wealth (Keister \& Borelli, 2014).

Not all recent immigrants have low levels of education, however. Because of changes to immigration laws, recent immigrants from other areas of the world (who are mostly of non-Christian faiths) are among the most educated of Americans today (Amin \& Sherkat, 2014; Cadge \& Ecklund, 2007; Read \& Eagle, 2014). For example, $85 \%$ of American Hindus have at least a bachelor's degree or more-more than double the percentage of Mainline Protestants and four times that of Evangelicals (see Table 2).

Our main point in this part is that, regardless of the initial causes and subsequent mechanisms associated with it, religious inequality remains. It is large, and if classical sociologists were right in their assessments more than a century ago, it is durable.

\section{Data and Methods}

For our analysis, we use both the GSS and the Pew 2014 Religious Landscape Survey. The GSS, conducted regularly since 1972, is a full probability interview study that measures both attitudinal and social characteristics of the U.S. (NORC at the University of Chicago, 2016). With a sample of approximately 1500 respondents per year, it is necessary to pool many years of the GSS together to get a large enough sample for advanced statistical analysis. Although we do this and control for year in an attempt to capture changes in the sample over time (1990-2016), we also replicate all of our analyses with a larger and more contemporary dataset to capture population changes that might not be adequately examined 
by just controlling for year - the Pew 2014 Religious Landscape Survey.

The 2014 Religious Landscape Survey is a telephone survey of more than 35,0000 respondents across the U.S., which probes on issues of religious identification, social and political attitudes, and demographic measures (Pew Research Center, 2015). We only present the tables from the GSS in the text but discuss differences between the GSS and Pew data when relevant. The Pew tables are available in the Annex at the end of this article.

We use the religious classification scheme, RelTrad (Steensland et al., 2000) which has been most commonly used by researchers, with nearly 900 publications utilizing this categorization (Stetzer \& Burge, 2016). On the basis of denominational affiliation, RelTrad sorts individuals into one of seven major religious traditions: Jewish, Mainline Protestant, Other religion, Nonaffiliated, Catholic, Evangelical Protestant, and Black Protestant.

While this study is focused on class differences, as we stated above, we do not restrict it to whites, and therefore include controls for gender and race in our models. We also include controls for: year, urban residence, Southern residence, and religious service attendance.

Year is measured by the GSS variable "year". Gender is captured by a dummy variable (using GSS variable "sex"), where female is defined as 1 and male is defined as 0 . Urban residence was measured using the GSS variable "res16", which asks respondents what type of place they were living at age 16 . We recoded this as a dummy variable, where " 1 " included categories of
"50,0000-250,000", "big city-suburb", and "city greater than 250,000" and 0 included the categories "county, nonfarm", "farm", and "town less than 50,0000". Southern residence is measured using GSS variable ("reg16"), which asks respondents where they were living at age 16 . We define it as a dummy variable, where Southern residence is " 1 " and includes residence in the categories of "South Atlantic", "East South Central", and "West South Central" and " 0 " for all other areas. Finally, religious service attendance is captured by the GSS variable "attend", which asks respondents how often they attend religious services. We recoded this as a dummy variable, where " 1 " captured high attenders (once a month or more) and " 0 " captured low attenders (several times a year or less).

We use four different measures of class in this study. Our first, and simplest measure is of the total number of years of education respondents report (GSS variable "educ"). Our second measure, "percent BA", is an aggregate score that we created of the percentage of members in each religious group with at least a bachelor's degree. Our third measure is the mean household income per capita of members in each religious group (in constant 2,000 U.S. dollars). Our fourth measure (GSS measure "sei10", which we will simply refer to as "SEI" henceforth) is a composite score that incorporates education, income and occupational prestige, thus providing an avenue to examine status as part of social class standing (Campbell \& Parker, 1983; Duncan, 1961; Haug, 1977; Hout, Smith, \& Marsden, 2016). Descriptive statistics for all of the variables we use in our models can be found below in Table 1.

Table 1. Descriptive statistics of variables.

\begin{tabular}{|c|c|c|c|c|c|}
\hline & Mean Proportion & SD & Min & Max & Observations \\
\hline Religious Tradition & & & & & 35499 \\
\hline Evangelical & 0.258 & & & & 9164 \\
\hline Mainline & 0.168 & & & & 5970 \\
\hline Black Protestant & 0.085 & & & & 3003 \\
\hline Catholic & 0.253 & & & & 8987 \\
\hline Jewish & 0.020 & & & & 708 \\
\hline Other Faith & 0.061 & & & & 2159 \\
\hline No Religion & 0.155 & & & & 5508 \\
\hline Education & 13.364 & 3.032 & 0 & 20 & 37476 \\
\hline SEI & 45.836 & 22.462 & 9 & 99.9 & 36007 \\
\hline Race & & & & & 37573 \\
\hline White & 0.781 & & & & 29329 \\
\hline Black & 0.142 & & & & 5351 \\
\hline Other & 0.077 & & & & 2893 \\
\hline Attendance & 3.631 & 2.753 & 0 & 8 & 37108 \\
\hline Age & 46.770 & 17.338 & 18 & 89 & 37463 \\
\hline Year & 2002.973 & 7.722 & 1990 & 2016 & 37573 \\
\hline Female & 0.558 & 0.497 & 0 & 1 & 37573 \\
\hline South & 0.311 & 0.463 & 0 & 1 & 37573 \\
\hline Urban & 0.449 & 0.497 & 0 & 1 & 35999 \\
\hline
\end{tabular}

Note: Data from GSS 1990-2016. 


\subsection{Methods}

The analysis that follows seeks to map the amount and contours of religious inequality today. We begin by examining basic cross-tabulations of a variety of measures of inequality (including income, mean year of schooling, proportion of members with at least a bachelor's degree, as well as examining each group's SEI to get a picture of the overall amount of inequality between groups). We then move to regression, first using Ordinary Least Squares (OLS) regression analyses to predict individual's years of education and SEI via religious group membership.

After finding that religion is a robust predictor of Americans' class backgrounds, we then turn to using education and socioeconomic background to predict reli- gious affiliation. Because religion is a nominal variable with more than two categories, we use Multinomial Logistic Regression in our next models, with Mainline Protestants as our reference category. After demonstrating that the relationship between class and religion is robust via these series of regression analyses as well, we then close by examining the amount of heterogeneity within each group. We do so by examining Ginicoefficients for the educational attainment and socioeconomic status of each of our religious groups.

\section{Findings}

Our first, most basic, but at the same time perhaps most important findings, are presented on Table 2, which presents data from the GSS.

Table 2. Variations in class by religious denominations, GSS 1990-2016 (ages 25-65). ${ }^{1}$

\begin{tabular}{|c|c|c|c|c|c|}
\hline & $\mathrm{N}$ & Mean Income (a) & Mean SEI (b) & $\begin{array}{l}\text { Mean Year of } \\
\text { Schooling (c) }\end{array}$ & $\%$ BA or More (d) \\
\hline Jewish & 482 & 42.68 & 61.38 & 16.10 & 68.46 \\
\hline Conservative Jewish & 107 & 42.49 & 61.59 & 16.36 & 74.77 \\
\hline Reform Jewish & 216 & 48.77 & 62.58 & 16.21 & 72.22 \\
\hline Other Jewish & 98 & 39.89 & 57.41 & 15.77 & 60.20 \\
\hline Orthodox Jewish & 38 & 22.40 & 59.56 & 15.55 & 57.89 \\
\hline Mainline Protestant & 4,024 & 29.12 & 51.07 & 14.33 & 38.52 \\
\hline Quaker & 29 & 33.48 & 59.56 & 15.10 & 55.17 \\
\hline Presbyterian-merged & 104 & 30.26 & 56.84 & 14.95 & 53.85 \\
\hline Episcopal & 500 & 35.91 & 56.87 & 15.36 & 52.00 \\
\hline Congregationalist (e) & 98 & 27.08 & 56.97 & 14.70 & 50.00 \\
\hline Disciples of Christ & 42 & 24.09 & 54.39 & 14.67 & 47.62 \\
\hline PCUSA (f) & 372 & 30.55 & 53.17 & 14.68 & 45.97 \\
\hline United Church of Christ & 59 & 33.47 & 54.03 & 14.51 & 42.37 \\
\hline Presbyterian-don't know which & 239 & 30.48 & 50.43 & 14.07 & 36.82 \\
\hline United Methodist* & 1,396 & 28.38 & 50.53 & 14.26 & 37.46 \\
\hline $\mathrm{ECLA}(\mathrm{g})$ & 537 & 26.89 & 49.38 & 14.20 & 34.08 \\
\hline Methodist-don't know which* & 222 & 24.48 & 46.21 & 13.42 & 24.77 \\
\hline American Baptist in the U.S. & 69 & 21.80 & 38.34 & 12.94 & 17.39 \\
\hline Other Religion & 1,693 & 23.75 & 49.80 & 14.33 & 37.86 \\
\hline Hindu & 76 & 30.89 & 70.30 & 16.55 & 85.53 \\
\hline Unitarian Universalist & 84 & 38.43 & 61.91 & 16.26 & 69.05 \\
\hline Buddhist & 135 & 32.36 & 56.72 & 15.19 & 58.52 \\
\hline Orthodox Christian & 80 & 25.12 & 51.10 & 15.00 & 52.50 \\
\hline Other Eastern & 31 & 31.68 & 59.34 & 14.67 & 45.16 \\
\hline Muslim & 117 & 17.94 & 48.84 & 14.18 & 38.46 \\
\hline Other Faith & 550 & 23.86 & 49.27 & 14.43 & 36.36 \\
\hline Mormon & 312 & 19.49 & 47.36 & 14.14 & 28.53 \\
\hline Jehovah's Witness & 209 & 15.43 & 36.67 & 11.79 & 5.26 \\
\hline No Religion & 4,243 & 26.26 & 48.14 & 14.00 & 33.44 \\
\hline Catholic & 6,668 & 24.78 & 46.43 & 13.48 & 28.99 \\
\hline White Catholics & 5,335 & 26.93 & 48.35 & 13.81 & 31.60 \\
\hline Other Catholics & 1,037 & 15.54 & 37.96 & 11.86 & 17.65 \\
\hline
\end{tabular}

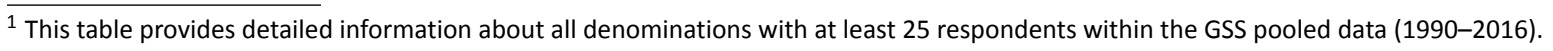


Table 2. Variations in class by religious denominations, GSS 1990-2016 (ages 25-65). (Cont.)

\begin{tabular}{|c|c|c|c|c|c|}
\hline & $\mathrm{N}$ & Mean Income (a) & Mean SEI (b) & $\begin{array}{l}\text { Mean Year of } \\
\text { Schooling (c) }\end{array}$ & $\%$ BA or More $(d)$ \\
\hline Evangelical Protestant & 6,828 & 21.36 & 44.28 & 13.17 & 21.32 \\
\hline Other Presbyterian & 90 & 28.80 & 52.65 & 14.81 & 46.67 \\
\hline Lutheran-MO Synod & 339 & 26.56 & 50.29 & 14.17 & 32.74 \\
\hline Nondenominational (h) & 1,118 & 23.74 & 48.29 & 14.04 & 32.65 \\
\hline Christian Reform & 44 & 21.50 & 45.70 & 13.91 & 31.82 \\
\hline Other Lutheran & 79 & 26.62 & 47.74 & 13.61 & 30.38 \\
\hline Independent & 30 & 20.48 & 49.19 & 13.97 & 30.00 \\
\hline Evangelist (i) & 74 & 16.12 & 45.34 & 12.77 & 28.38 \\
\hline Brethren (j) & 26 & 19.65 & 46.17 & 12.69 & 26.92 \\
\hline Christian, Central Christian & 207 & 20.00 & 46.68 & 13.36 & 26.09 \\
\hline Other Methodist* & 47 & 24.80 & 47.78 & 13.72 & 25.53 \\
\hline Lutheran-don't know which & 292 & 27.73 & 45.87 & 13.52 & 25.00 \\
\hline Church of Christ & 265 & 22.85 & 44.85 & 13.35 & 21.51 \\
\hline 7th Day Adventist & 99 & 18.47 & 43.36 & 13.08 & 20.20 \\
\hline Lutheran-WI synod & 91 & 22.73 & 45.83 & 13.44 & 19.78 \\
\hline Nazarene & 76 & 24.16 & 42.74 & 13.41 & 19.74 \\
\hline Other Baptist* & 307 & 20.61 & 45.17 & 13.20 & 19.22 \\
\hline Southern Baptist* & 1,655 & 22.02 & 44.27 & 13.06 & 19.15 \\
\hline Assembly of God & 149 & 19.33 & 45.13 & 12.87 & 16.78 \\
\hline American Baptist Association* & 191 & 22.62 & 40.09 & 12.68 & 15.71 \\
\hline Other Fundamentalist & 26 & 20.12 & 40.73 & 12.15 & 15.38 \\
\hline Churches of God (k) & 103 & 15.48 & 40.36 & 12.17 & 13.59 \\
\hline Freewill Baptist & 63 & 15.34 & 39.96 & 12.67 & 11.11 \\
\hline Baptist- Don't know which* & 936 & 18.86 & 38.77 & 12.29 & 10.68 \\
\hline Pentecostal & 520 & 15.40 & 38.79 & 12.20 & 9.42 \\
\hline Pentecostal Holiness (I) & 33 & 12.43 & 39.59 & 12.12 & 9.09 \\
\hline Black Protestant & 2,310 & 16.53 & 37.81 & 12.82 & 14.29 \\
\hline African Methodist Episcopal Zion & 47 & 16.65 & 42.82 & 13.49 & 27.66 \\
\hline National Baptist Convention in America & 103 & 23.05 & 40.12 & 13.58 & 22.33 \\
\hline National Baptist Convention in the USA & 60 & 20.84 & 42.88 & 13.52 & 21.67 \\
\hline African Methodist Episcopal & 105 & 18.01 & 41.44 & 13.22 & 20.00 \\
\hline Southern Baptist+ & 512 & 17.71 & 39.24 & 13.01 & 16.21 \\
\hline Other Baptist+ & 94 & 17.34 & 38.28 & 12.51 & 15.96 \\
\hline Baptist- Don't know which+ & 863 & 15.68 & 37.32 & 12.80 & 13.33 \\
\hline Apostolic Faith & 25 & 21.48 & 40.03 & 12.24 & 12.00 \\
\hline American Baptist Association+ & 174 & 13.64 & 35.79 & 12.47 & 11.49 \\
\hline American Baptists in the U.S.+ & 118 & 14.05 & 33.25 & 12.31 & 8.47 \\
\hline Church of God in Christ & 25 & 11.51 & 33.94 & 12.88 & 8.00 \\
\hline Missionary Baptist+ & 31 & 16.38 & 35.93 & 12.48 & 3.23 \\
\hline Methodist- Don't know which+ & 39 & 15.27 & 33.24 & 12.56 & 2.56 \\
\hline Holiness (m) & 62 & 11.62 & 28.85 & 11.28 & 1.61 \\
\hline
\end{tabular}

Notes: (a) Household income per capita in 1,000 dollars, adjusted to 2,000 constant dollars; (b) GSS variable "sei10"; (c) GSS variable "Educ"; (d) using GSS variable "Degree", values are combined for respondents with a bachelor's degree or a graduate degree; (e) GSS category "Congregationalist, 1st Congregationalist"; (f) PCUSA includes "Presbyterian Church in U.S". and "United Presbyterian Church in U.S" categories; (g) ECLA includes "Lutheran Church in America", "American Lutheran", and "Evangelical Lutheran" categories; (h) included only if respondents attended church more than once a month (ATTEND < 4); (i) GSS category "Evangelical; Evangelist"; (j) GSS category "Brethren Church; Brethren"; (k) GSS category "Churches of God (except with Christ and Holiness)"; (I) GSS category "Pentecostal Holiness; Holiness Pentecostal"; (m) GSS category "Holiness; Church of Holiness"; *Included only if race is not black; +Included only if race is black.

Through simple cross-tabulations of individuals by religious tradition, Table 2 demonstrates that profound socioeconomic differences remain between American religious groups.
Whether we examine mean year of schooling, mean income, the percent with BAs, or mean SEI score, the picture remains the same with small variations. 
By far the most important differences exist between the two categories of white Protestants on Table 2. Mainline Protestants have almost twice the percentage of people with BAs as Evangelical Protestants. The other measures tell the same story. With a mean SEI of 51 and an average household income that is nearly one-third larger than Evangelicals, Mainline Protestants are doing very well economically.

Also doing well are those of other religions and no religion, with SEI scores almost equivalent to Mainline Protestants, although those of other faiths have incomes that are much lower-approaching that of Evangelicals. Catholics are generally doing better than Evangelicals, but not as well as the other groups in our analysis.

Figure 1 illustrates this overall pattern by the percentage of each group that has a bachelor's degree or more. This simple picture clearly illustrates the major educational differences that remain among American religious groups. Jews remain the most highly educated group by far, while Black Protestants have the lowest proportion of members with bachelor's degrees or more.

In addition, Figure 1 also demonstrates that members of "Other religions" such as Hindus, Buddhists, and Muslims, are generally quite highly educated. This is most likely a result of more recent immigration and an artifact of American immigration laws, which select the highly educated from many areas of the world. Figure 1 also demonstrates the relatively highly educated nature of those who profess no religion, an evergrowing proportion of the population (Hout \& Fischer, 2002, 2014; Sherkat, 2014). The percentage of Nones who have a bachelor's degree is almost equal to that of Mainline Protestants. Finally, Figure 1 also demonstrates that Catholics remain less educated than Mainline Protestants, ${ }^{2}$ something expected because of recent Latino immigration, but are more educated that white Evangelical Protestants.

\subsection{Predicting Class by Religion}

Cross-tabulations, although useful, do not allow us to examine more complex relationships. Thus, we turn to Table 3 , which uses religion to predict years of education and SEI via Ordinary Least Squares regression techniques with standard controls. Table 3 demonstrates that the class and educational differences between religious traditions are both substantively and statistically significant. When compared to Mainline Protestants, every group except Jews and those of other religions is significantly worse off.

First, Model 1 demonstrates the significant educational disadvantage that white Evangelical Protestants experience relative to white Mainline Protestants (our reference category) - with 1.2 fewer years of education predicted. White Evangelical Protestants are the only white group that is predicted to have barely more than one year of education post high school. Model 2 demonstrates that the picture is largely the same for SEI. Predicted probabilities of both models are presented pictorially in Figures 2 and 3.

The predicted probabilities demonstrate that similar proportions of Mainline Protestants, those of no religion, and those from other religious have about two years of higher education. Evangelicals and Catholics peak a full year earlier.

Figure 3, which presents the predicted percentage of members of each religious group with various SEI scores, presents the most complete picture of economic advantage and disadvantage, with the overall class advantage of Mainline Protestants coming into view more clearly. Second only to Jews in SEI, almost $70 \%$ of Mainline Protestants have a predicted SEI between 45-50. In comparison, nearly three-quarters of Evangelicals have a predicted SEI of 40 or below.

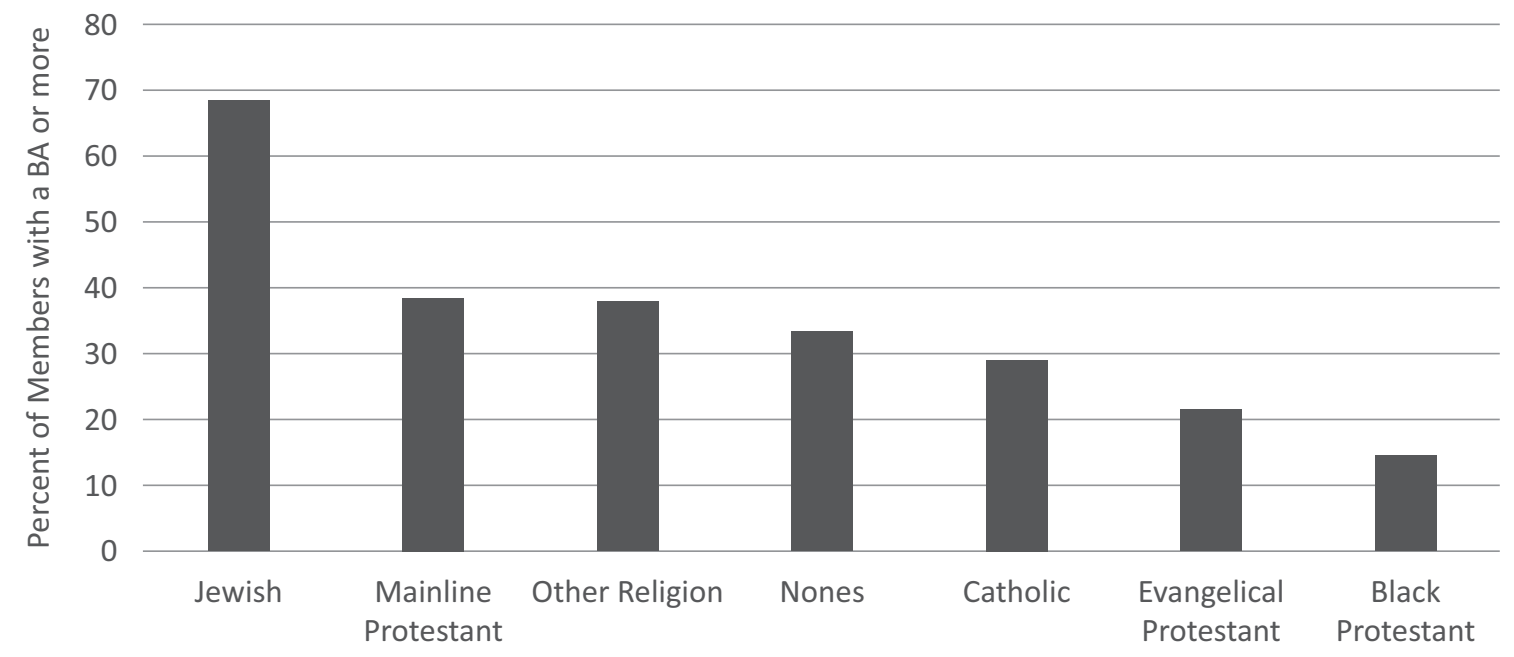

Figure 1. Variations in education by religious group, GSS 1990-2016.

\footnotetext{
$\overline{2}$ This gap has lessened in the Pew data, which is to be expected as it is more contemporary data.
} 
Table 3. Effects of religion on years of education and SEI, GSS 1990-2016.

\begin{tabular}{|c|c|c|}
\hline & $\begin{array}{l}\text { Model } 1 \\
\text { Education }\end{array}$ & $\begin{array}{l}\text { Model } 2 \\
\text { SEI }\end{array}$ \\
\hline Mainline Protestant & Reference & Reference \\
\hline Evangelical & $\begin{array}{l}-1.306^{* * *} \\
(.050)\end{array}$ & $\begin{array}{l}-6.884^{* * *} \\
(.387)\end{array}$ \\
\hline Black Protestant & $\begin{array}{l}-.937^{* * *} \\
(.088)\end{array}$ & $\begin{array}{l}-6.661^{* * *} \\
(.690)\end{array}$ \\
\hline Catholic & $\begin{array}{l}-1.043 * * * \\
(.050)\end{array}$ & $\begin{array}{l}-5.275^{* * *} \\
(.388)\end{array}$ \\
\hline Jewish & $\begin{array}{l}1.332^{* * *} \\
(.118)\end{array}$ & $\begin{array}{l}8.296 * * * \\
(.909)\end{array}$ \\
\hline Other Religion & $\begin{array}{l}-.171^{*} \\
(.075)\end{array}$ & $\begin{array}{l}-1.055 \\
(.582)\end{array}$ \\
\hline No Religion & $\begin{array}{l}-.205^{* * *} \\
(.060)\end{array}$ & $\begin{array}{l}-.708 \\
(.462)\end{array}$ \\
\hline White & Reference & Reference \\
\hline Black & $\begin{array}{l}-1.015^{* * *} \\
(.065)\end{array}$ & $\begin{array}{l}-7.847^{* * *} \\
(.507)\end{array}$ \\
\hline Other Race & $\begin{array}{l}-1.128^{* * *} \\
(.061)\end{array}$ & $\begin{array}{l}-4.306^{* * *} \\
(.481)\end{array}$ \\
\hline Attendance & $\begin{array}{l}.150 * * * \\
(.006)\end{array}$ & $\begin{array}{l}.892^{* * *} \\
(.050)\end{array}$ \\
\hline Age & $\begin{array}{l}-.026^{* * *} \\
(.001)\end{array}$ & $\begin{array}{l}.056 * * * \\
(.007)\end{array}$ \\
\hline Year & $\begin{array}{l}.035^{* * *} \\
(.002)\end{array}$ & $\begin{array}{l}.117^{* * *} \\
(.016)\end{array}$ \\
\hline Female & $\begin{array}{l}-.154^{* * *} \\
(.032)\end{array}$ & $\begin{array}{l}-3.272^{* * *} \\
(.246)\end{array}$ \\
\hline South & $\begin{array}{l}-.421^{* * *} \\
(.036)\end{array}$ & $\begin{array}{l}-1.365^{* * *} \\
(.282)\end{array}$ \\
\hline Urban & $\begin{array}{l}.823^{* * *} \\
(.033)\end{array}$ & $\begin{array}{l}4.978^{* * *} \\
(.251)\end{array}$ \\
\hline $\mathrm{R}^{2}(\%)$ & 10.98 & 6.77 \\
\hline $\mathrm{N}$ & 33544 & 32201 \\
\hline
\end{tabular}

Notes: Standard errors in parentheses; ${ }^{*}<.05,{ }^{* *}<.01,{ }^{* * *}<.001$.

\subsection{Predicting Religion by Class}

As we noted earlier, the point of this article is not to make a causal argument but rather to demonstrate the interrelated nature of class and religion in the U.S. Thus, our next set of analyses switches our dependent and independent variables and use SEI and education to predict religious group membership using Multinomial Logistic Regression. These analyses are presented on Tables 4 and 5 and illustrated by Figures 4 and 5 .

Figures 4 and 5 demonstrate that the probability of being in a particular religious group changes significantly as our indicators of class background rise, whether we use a simple measure of education or the more complex measure of SEI. Of course, these predictions are dependent to some extent on the relative proportion of each group in the GSS (see Table 1 for the relative proportions).
However, the point here is that these religious groups are not evenly distributed across socioeconomic groups.

Individuals with low SEls (less than a high school education and low occupational prestige and income) are twice as likely to be Evangelical Protestant as Mainline Protestant and four times as likely to be Evangelical than to be Jewish or some other religion. At the other end of the class spectrum, individuals with a high SEI (more than a college degree and a high occupational prestige and income) are $50 \%$ more likely to be Mainline Protestant than Evangelical Protestant or Catholic.

\subsection{Educational Homogeneity}

Finally, just as there is more socioeconomic inequality between some groups than others, some groups are more heterogeneous class-wise than others. 


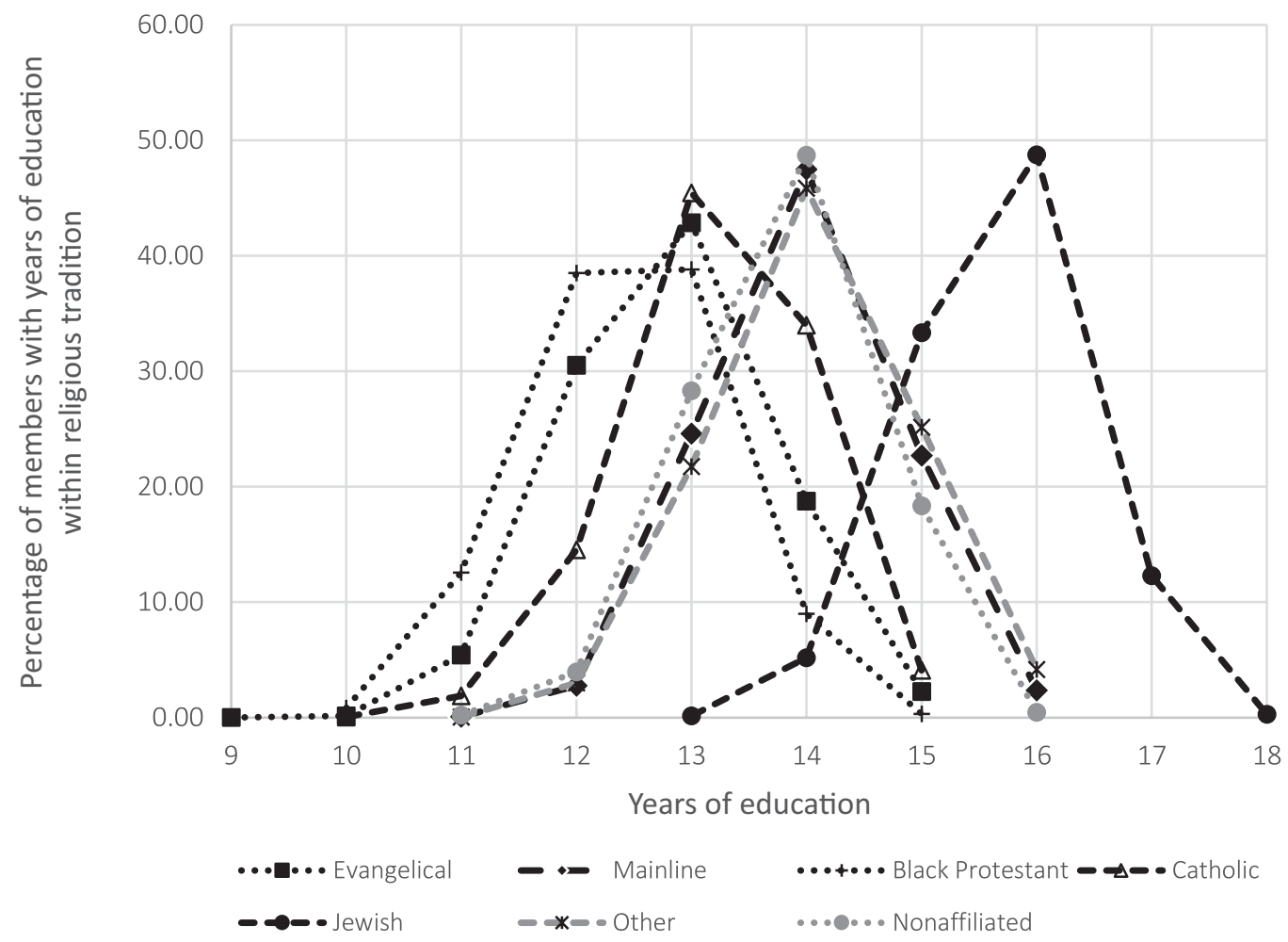

Figure 2. Predicted percentage of members with education level by religious tradition, GSS 1990-2016.

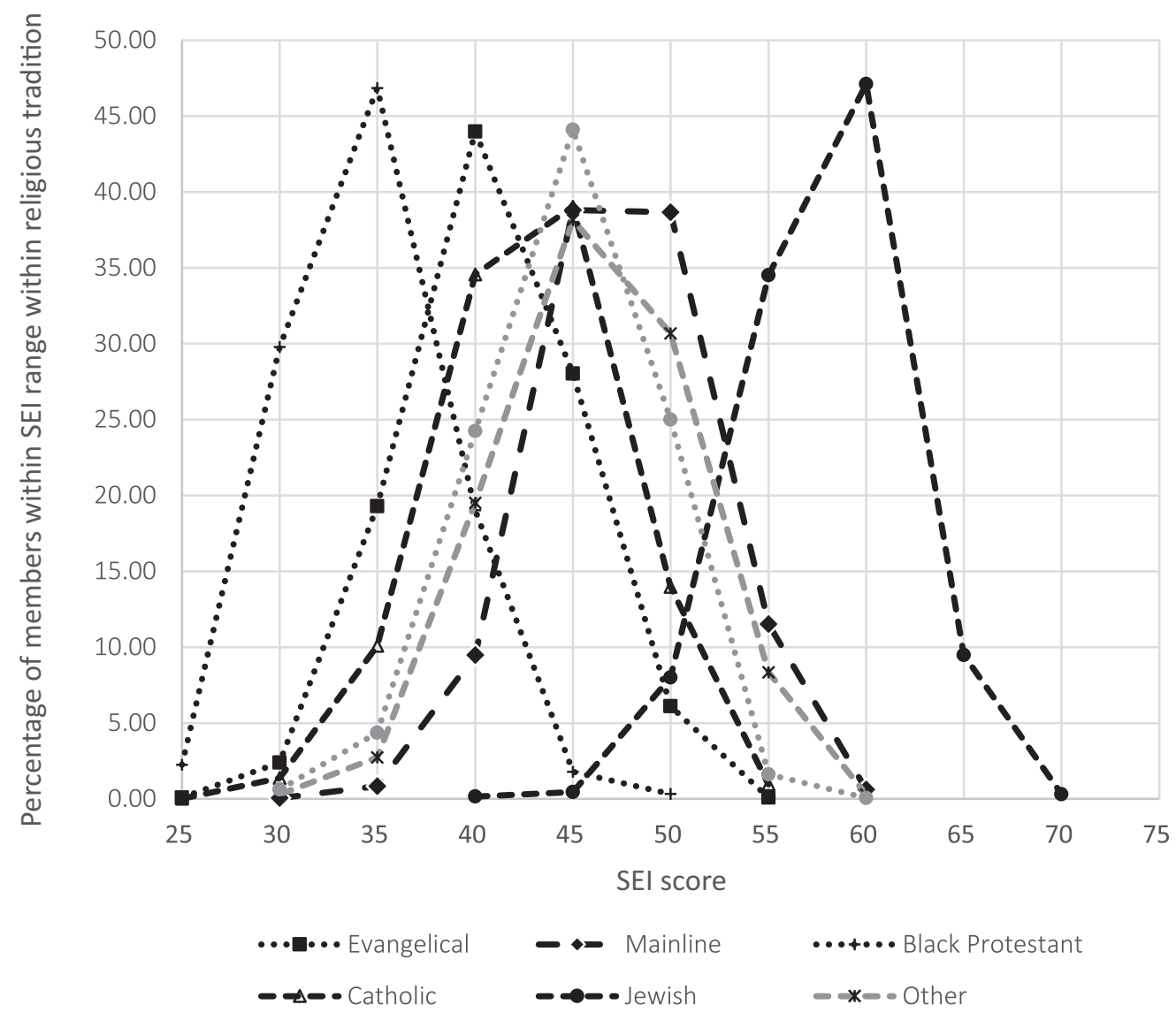

...... Nonaffiliated

Figure 3. Predicted percentage of members' SEI score by religious tradition, GSS 1990-2016. 
Table 4. The likelihood of religious group membership by education.

\begin{tabular}{|c|c|c|c|c|c|c|}
\hline & Evangelical & Black Protestant & Catholic & Jewish & Other Religion & No Religion \\
\hline \multirow[t]{2}{*}{ Education } & $0.847 * * *$ & $0.874^{* * *}$ & $0.876^{* * *}$ & $1.192 * * *$ & $0.975^{* * *}$ & 1.003 \\
\hline & $(0.005)$ & $(0.010)$ & $(0.006)$ & $(0.018)$ & $(0.009)$ & $(0.008)$ \\
\hline White & Reference & Reference & Reference & Reference & Reference & Reference \\
\hline \multirow[t]{2}{*}{ Black } & 1.054 & $397.759 * * *$ & $0.842 * *$ & $0.492 * *$ & $2.873 * * *$ & $3.642 * * *$ \\
\hline & $(0.085)$ & $(48.591)$ & $(0.074)$ & $(0.138)$ & $(0.285)$ & $(0.336)$ \\
\hline \multirow[t]{2}{*}{ Other Race } & $1.802^{* * *}$ & $6.913^{* * *}$ & $5.238 * * *$ & $0.513^{*}$ & $9.120 * * *$ & $3.085^{* * *}$ \\
\hline & $(0.203)$ & $(1.941)$ & $(0.542)$ & $(0.181)$ & $(1.041)$ & $(0.357)$ \\
\hline \multirow[t]{2}{*}{ Attendance } & $1.205^{* * *}$ & $1.024 *$ & $1.073 * * *$ & $0.846^{* * *}$ & $1.046 * * *$ & $0.506^{* * *}$ \\
\hline & $(0.008)$ & $(0.014)$ & $(0.007)$ & $(0.015)$ & $(0.011)$ & $(0.007)$ \\
\hline \multirow[t]{2}{*}{ Age } & $0.977 * * *$ & $0.987^{* * *}$ & $0.977 * * *$ & 1.002 & $0.971 * * *$ & $0.957^{* * *}$ \\
\hline & $(0.001)$ & $(0.002)$ & $(0.001)$ & $(0.003)$ & $(0.002)$ & $(0.001)$ \\
\hline \multirow[t]{2}{*}{ Year } & $1.029 * * *$ & 1.002 & $1.028 * * *$ & 1.004 & $1.024^{* * *}$ & $1.068^{* * *}$ \\
\hline & $(0.002)$ & $(0.004)$ & $(0.002)$ & $(0.006)$ & $(0.004)$ & $(0.003)$ \\
\hline \multirow[t]{2}{*}{ Female } & $0.885^{* * *}$ & 1.043 & $0.863 * * *$ & 0.953 & $0.863 * * *$ & $0.646 * * *$ \\
\hline & $(0.032)$ & $(0.070)$ & $(0.031)$ & $(0.080)$ & $(0.046)$ & $(0.028)$ \\
\hline \multirow[t]{2}{*}{ South } & $1.970 * * *$ & $2.054^{* * *}$ & $0.416 * * *$ & $0.524 * * *$ & $0.528 * * *$ & $0.701^{* * *}$ \\
\hline & $(0.075)$ & $(0.144)$ & (0.018) & $(0.060)$ & $(0.035)$ & $(0.036)$ \\
\hline \multirow[t]{2}{*}{ Urban } & 0.972 & $1.152 * *$ & $1.776 * * *$ & $6.858 * * *$ & $1.606 * * *$ & $1.541^{* * *}$ \\
\hline & (0.037) & $(0.081)$ & $(0.066)$ & $(0.722)$ & $(0.087)$ & $(0.069)$ \\
\hline
\end{tabular}

Notes: Number of observations is 33544. Pseudo R-squared is .2433. Standard errors in parentheses. ${ }^{*}<.05, * *<.01, * * *<.001$.

Table 5. The likelihood of religious group membership by SEI.

\begin{tabular}{|c|c|c|c|c|c|c|}
\hline & Evangelical & Black Protestant & Catholic & Jewish & Other Religion & No Religion \\
\hline \multirow[t]{2}{*}{ SEI } & $0.985^{* * *}$ & $0.986 * * *$ & $0.989 * * *$ & $1.017 * * *$ & $0.998^{*}$ & 1.002 \\
\hline & $(0.001)$ & $(0.002)$ & $(0.001)$ & $(0.002)$ & $(0.001)$ & $(0.001)$ \\
\hline White & Reference & Reference & Reference & Reference & Reference & Reference \\
\hline \multirow[t]{2}{*}{ Black } & 1.123 & $416.589 * * *$ & 0.867 & $0.502 * *$ & $2.874 * * *$ & $3.748 * * *$ \\
\hline & $(0.093)$ & $(52.366)$ & $(0.078)$ & $(0.141)$ & $(0.295)$ & $(0.357)$ \\
\hline \multirow[t]{2}{*}{ Other Race } & $2.071 * * *$ & $7.150 * * *$ & $5.693 * * *$ & $0.452 * *$ & $9.214^{* * *}$ & $3.182 * * *$ \\
\hline & $(0.239)$ & $(2.117)$ & $(0.607)$ & $(0.178)$ & (1.088) & $(0.380)$ \\
\hline \multirow[t]{2}{*}{ Attendance } & $1.194^{* * *}$ & 1.015 & $1.065^{* * *}$ & $0.852 * * *$ & $1.040 * * *$ & $0.507 * * *$ \\
\hline & $(0.008)$ & $(0.015)$ & $(0.007)$ & $(0.015)$ & $(0.011)$ & $(0.007)$ \\
\hline \multirow[t]{2}{*}{ Age } & $0.982 * * *$ & $0.990 * * *$ & $0.981 * * *$ & 0.999 & $0.973 * * *$ & $0.958 * * *$ \\
\hline & $(0.001)$ & $(0.002)$ & $(0.001)$ & $(0.003)$ & $(0.002)$ & $(0.001)$ \\
\hline \multirow[t]{2}{*}{ Year } & $1.025^{* * *}$ & 0.998 & $1.024 * * *$ & 1.007 & $1.022 * * *$ & $1.068 * * *$ \\
\hline & $(0.002)$ & $(0.004)$ & $(0.002)$ & $(0.006)$ & $(0.004)$ & $(0.003)$ \\
\hline \multirow[t]{2}{*}{ Female } & $0.854^{* * *}$ & 1.034 & $0.841 * * *$ & 0.944 & $0.859 * * *$ & $0.646 * * *$ \\
\hline & $(0.031)$ & $(0.071)$ & $(0.031)$ & $(0.081)$ & $(0.047)$ & $(0.029)$ \\
\hline \multirow[t]{2}{*}{ South } & $2.094^{* * *}$ & $2.178 * * *$ & $0.433^{* * *}$ & $0.493^{* * *}$ & $0.544^{* * *}$ & $0.699 * * *$ \\
\hline & $(0.080)$ & $(0.157)$ & (0.019) & $(0.058)$ & $(0.037)$ & $(0.036)$ \\
\hline \multirow[t]{2}{*}{ Urban } & $0.920 * *$ & $1.142^{*}$ & $1.703^{* * *}$ & $7.425^{* * *}$ & $1.618^{* * *}$ & $1.539 * * *$ \\
\hline & $(0.035)$ & $(0.082)$ & $(0.063)$ & $(0.801)$ & $(0.089)$ & $(0.070)$ \\
\hline
\end{tabular}

Notes: Number of observations is 32201. Pseudo R-squared is .2367. Standard errors in parentheses. ${ }^{*}<.05,{ }^{* *}<.01,{ }^{* * *}<.001$.

Table 6 presents Gini-coefficients for the educational attainment and socioeconomic status of each of our religious groups. A Gini-coefficient is a measure of inequality in the distribution of a variable. Its value ranges from 0 to 1 , where 0 is perfect equality and 1 is perfect inequality (Beckfield, 2006; Firebaugh, 1999). Both Ginis provide interesting, and somewhat different, perspectives on religious inequality.
The education Gini, which Figure 6 helps to visualize, demonstrates that Jews and Evangelical Protestants are quite distinct educationally, both being more homogeneous than the other groups. The median is represented by the horizontal line cutting through the center of most of the boxes, with the exception of the Evangelical box (for which the median overlaps with the bottom quartile). The dots represent the presence of outliers, or re- 


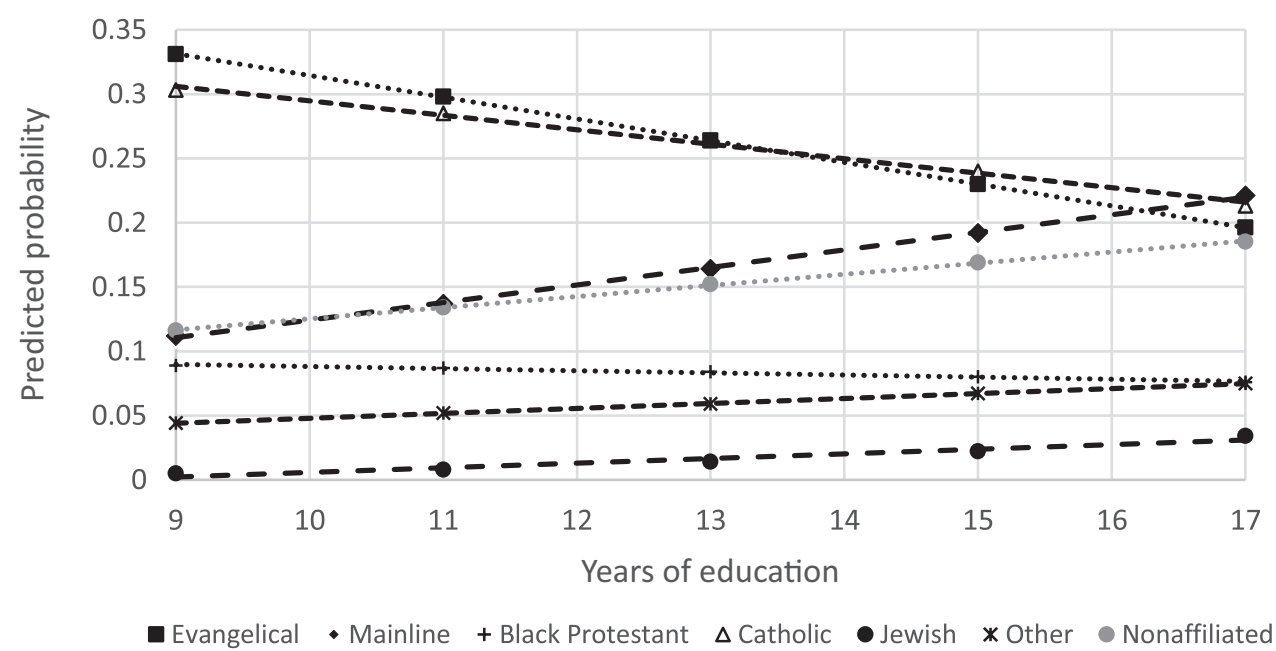

Figure 4. The likelihood of being a particular religious group by years of education, GSS 1990-2016.

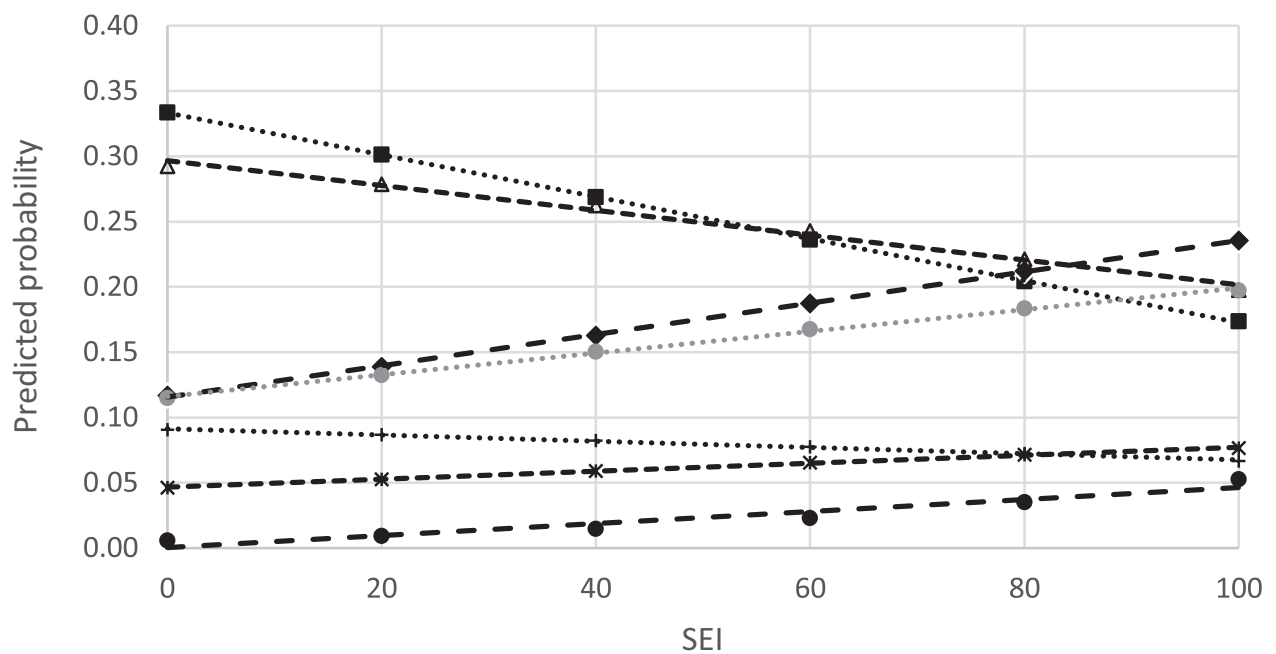

Evangelical - Mainline + Black Protestant $\Delta$ Catholic $\bullet$ Jewish $*$ Other $\bullet$ Nonaffiliated

Figure 5. The likelihood of being a particular religious group by socioeconomic background, GSS 1990-2016.

Table 6. Education and SEI Gini-coefficients.

\begin{tabular}{lll}
\hline & Education & SEI \\
\hline Evangelical & 0.116 & 0.274 \\
Mainline & 0.110 & 0.257 \\
Black Protestant & 0.114 & 0.297 \\
Catholic & 0.125 & 0.281 \\
Jewish & 0.097 & 0.203 \\
Other Faith & 0.121 & 0.275 \\
No Religion & 0.116 & 0.280 \\
\hline
\end{tabular}

Notes: Data from GSS 1990-2016. Weights are used.

spondents who are more than 1.5 times the interquartile range in either direction. The first quartile for Jews is higher than the medians for the other religious traditions, which demonstrates that most Jews are highly educated. Among Evangelical Protestants, the first quartile and median are the same (12 years). This means at least $25 \%$ of Evangelical Protestants in our sample have 12 years of education, which makes the distribution of years of education for Evangelical Protestants quite dense.
Catholics, Mainline Protestants and the nonreligious are much more educationally heterogeneous, but less so than people of other faiths who are the most widely dispersed educationally. This is the case even though those of other faiths have the second highest years of education on average, suggesting a fairly educationally diverse group.

The picture is the same when socioeconomic heterogeneity is examined in Figure 7, except that Mainline 


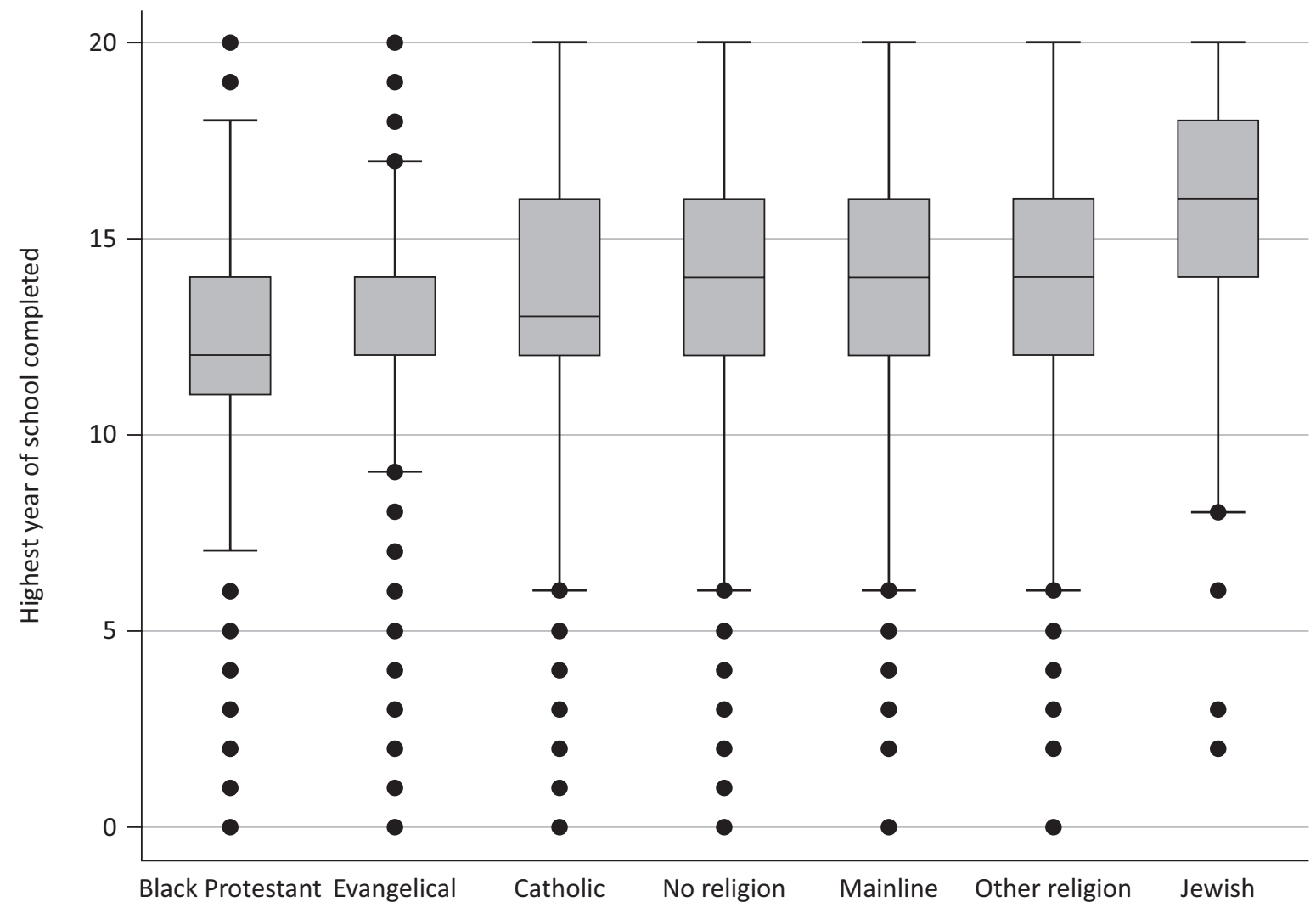

Figure 6. Educational heterogeneity by religious tradition.

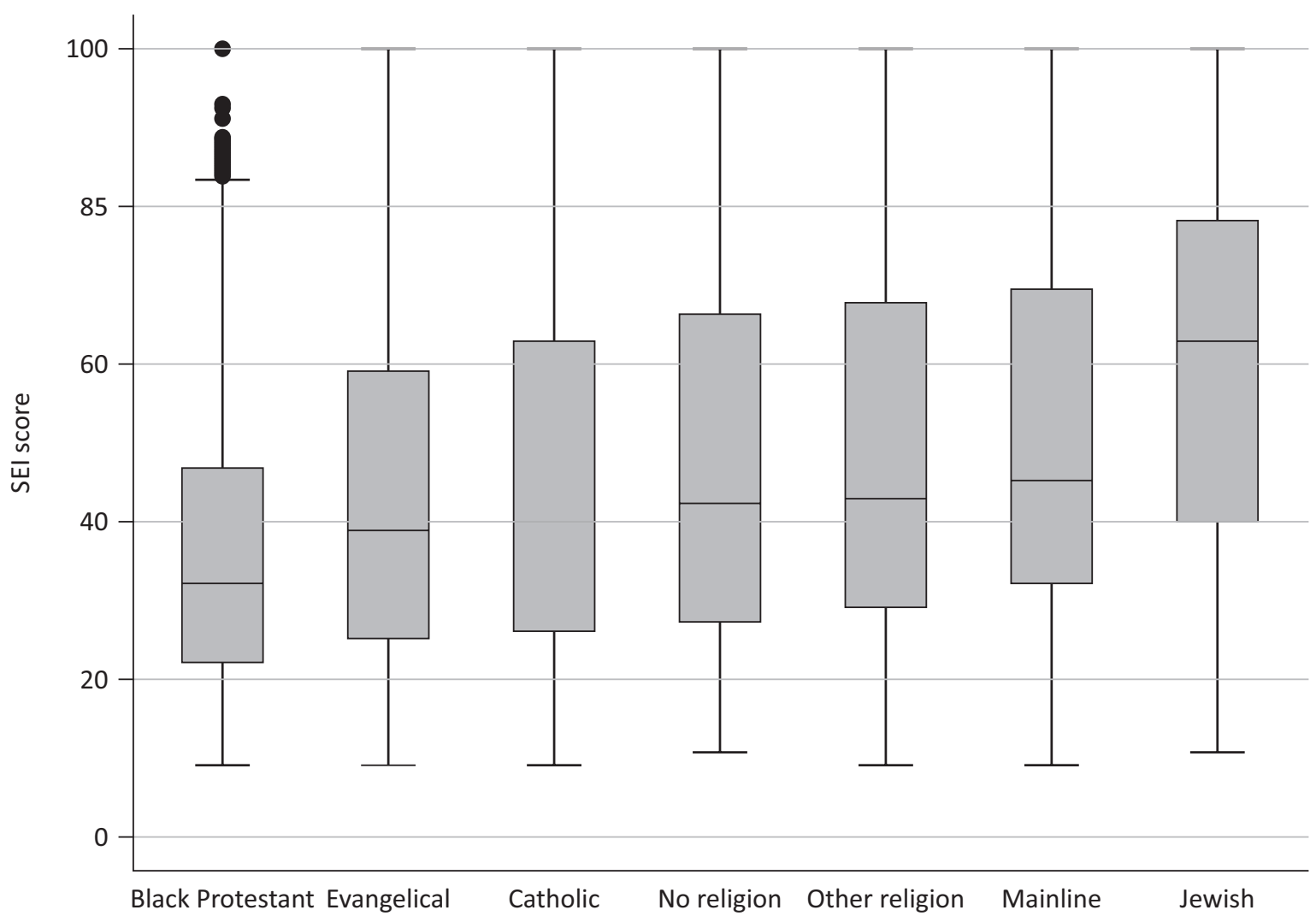

Figure 7. Socioeconomic heterogeneity by religious tradition. 
Protestants emerge as more clearly advantaged socioeconomically with the second highest SEI and a moderate standard deviation, which means most Mainline Protestants are also high SEI. People of other faiths, on average, have the third highest SEI, yet they are the most widely dispersed socioeconomically, again suggesting a wide diversity of socioeconomic backgrounds among this group.

\section{Conclusion}

Religious inequality remains strong in the U.S. Originally, the "gatekeepers" of American society (Davidson \& Pyle, 2011), Mainline Protestants remain at the top of the socioeconomic ladder, with almost $40 \%$ of them having a bachelor's degree or more on average (see Table 2). Even so, the legacy of the different histories and settlement patterns of Mainline Protestant denominations can still be seen. For example, more than $50 \%$ of members from groups that would have been considered part of the Protestant establishment (Baltzell, 1964)-Congregationalist, Episcopalians, Presbyterians, and Quakers-have a bachelor's degree or more. However, some groups in the Mainline Protestant category as operationalized by RelTrad, groups that were arguably not a part of Mainline Protestantism historically, such as the American Baptists in the U.S., have lower percentages of highly educated members. As a result, the educational Gini on Table 6 and Figure 6 demonstrate that Mainline Protestants as operationalized by RelTrad are one of the most educationally heterogeneous groups today.

Despite the fact that the Mainline Protestant category is quite heterogenous, however, there are two additional important points to note. Socioeconomically, it appears Mainline Protestants are doing better than more recent immigrants who have been selected for their educational credentials, such as those from other religions. Secondly, they remain educationally and socioeconomically quite distinct from Evangelicals. Evangelical Protestants have only half the proportion of members with bachelor's degrees as Mainline Protestants. Evangelical Protestants' lower educational attainment is also a result of greater educational homogeneity, as illustrated by Figure 6.

Jews have surpassed even the most educated Mainline Protestants, with $68 \%$ of Jews having a bachelor's degree or more (see Table 2), a proportion that is surpassed only by the $85 \%$ American Hindus with a college degree or more. However, one should not fail to forget that groups such as Unitarian Universalist, who are today not included within Mainline Protestantism because of their "unorthodox" beliefs, were part of the Protestant Establishment. Today, 69\% of Unitarian Universalists have a bachelor's degree or more-more than Jews on average.

Those of no religion are also fairly well educated, having 1.5 times the proportion of college degrees as Evangelical Protestants.
The analyses presented in this article also demonstrate that Catholics have indeed entered the middle class (see Table 2), with almost $30 \%$ of them having bachelor's degrees or more overall. However, this is not the case for all Catholics, as Latino Catholics remain at an educational disadvantage relative to the descendants of earlier Roman Catholic immigrants. This ethnic and historical diversity makes American Catholics one of the most heterogeneous religious groups in the U.S. todaywith a lower median but similar distribution to Mainline Protestants, Nones, and those of other religions.

Finally, Black Protestants remain at the greatest educational and economic disadvantage of all American religious groups, having less than half the proportion of bachelor's degrees as Catholics or those of no religion.

Given the significant differences in the class backgrounds of American religious groups that we have presented here, we argue that researchers should not treat measures of class such as socioeconomic background and education as if they are independent from religion in statistical analyses. Instead we recommend that researchers examine religion in interaction with measures of class in analyses whenever possible. Doing so will allow religion's intersections with other social structures to show through in all its complexity.

\section{Acknowledgements}

We would like thank Clem Brooks, John Diulio, Chenoa Flippen, Conrad Hackett, Mike Hout, Jerry Park, and Landon Schnabel for their helpful comments and suggestions on earlier versions of this article. We would like to thank Penn's Program for Research on Religion and Urban Civil Society for financial and other support over the course of this project.

\section{Conflict of Interests}

The authors declare no conflict of interests.

\section{References}

Amin, N., \& Sherkat, D. E. (2014). Religion, gender, and educational attainment among U.S. immigrants: Evidence from the New Immigrant Survey. In Religion and inequality in America: Research and theory on religion's role in stratification (pp. 52-74). New York, NY: Cambridge University Press.

Baltzell, E. D. (1964). The Protestant establishment: Aristocracy and caste in America. New Haven, CT: Yale University Press.

Beckfield, J. (2006). European integration and income inequality. American Sociological Review, 71(6), 964985. https://doi.org/10.1177/000312240607100605

Beyerlein, K. (2004). Specifying the impact of Conservative Protestantism on educational attainment. Journal for the Scientific Study of Religion, 43(4), 505-518. https://doi.org/10.1111/j.1468-5906.2004.00252.x 
Blau, F. D., \& Kahn, L. M. (2006). The U.S. gender pay gap in the 1990S: Slowing convergence. ILR Review, 60(1), 45-66. https://doi.org/10.1177/ 001979390606000103

Blau, F. D., \& Kahn, L. M. (2016). The gender wage gap: Extent, trends, and explanations (Working Paper no. 21913). Cambridge, MA: National Bureau of Economic Research. https://doi.org/10.3386/w21913

Bourdieu, P. (1984). Distinction: A social critique of the judgement of taste (R. Nice, Trans.). Cambridge, MA: Harvard University Press.

Brown, A., \& Patten, E. (2017). The narrowing, but persistent, gender gap in pay. Pew Research. Retrieved from http://www.pewresearch.org/fact-tank/2017/ 04/03/gender-pay-gap-facts

Cadge, W., \& Ecklund, E. H. (2007). Immigration and religion. Annual Review of Sociology, 33(1), 359-379. https://doi.org/10.1146/annurev.soc.33. 040406.131707

Campbell, R. T., \& Parker, R. N. (1983). Substantive and statistical considerations in the interpretation of multiple measures of SES. Social Forces, 62(2), 450-466. https://doi.org/10.1093/sf/62.2.450

Cantril, H. (1943). Educational and economic composition of religious groups: An analysis of poll data. American Journal of Sociology, 48(5), 574-579.

Choo, H. Y., \& Ferree, M. M. (2010). Practicing intersectionality in sociological research: A Critical analysis of inclusions, interactions, and institutions in the study of inequalities. Sociological Theory, 28(2), 129-149. https://doi.org/10.1111/j.1467-9558.2010.01370.x

Coe, D. L., \& Davidson, J. D. (2014). The religious affiliation of Ivy League presidents 1636-2012: A study in religious stratification. In Religion and inequality in America: Research and theory on religion's role in stratification (pp. 146-169). New York, NY: Cambridge University Press.

Darnell, A., \& Sherkat, D. E. (1997). The impact of Protestant fundamentalism on educational attainment. American Sociological Review, 62(2), 306-315.

Davidson, J. D., \& Pyle, R. E. (2011). Ranking faiths: Religious stratification in America. Lanham, MD: Rowman \& Littlefield Publishers.

Demerath, N. J. (1965). Social class in American Protestantism. Chicago, IL: Rand McNally.

Duncan, O. D. (1961). A socioeconomic index for all occupations. In A. J. Reiss (Ed.), Occupation and social status (pp. 109-138). New York, NY: Free Press of Glencoe.

Eagle, D. E. (2012). Mega, medium, and mini: Size and the socioeconomic status composition of American Protestant churches. In L. A. Keister, J. Mccarthy, \& R. Finke (Eds.), Religion, work and inequality (Vol. 23, pp. 281-307). Bradford: Emerald Group Publishing Limited. https://doi.org/10.1108/S02772833(2012)0000023015

Ellis, R. (2015). Outreach and exclusion: Jewish denominational marketing in the early 20th century. Jour- nal for the Scientific Study of Religion, 54(1), 38-56. https://doi.org/10.1111/jssr.12167

Finke, R., \& Stark, R. (2005). The churching of America, 1776-2005: Winners and losers in our religious economy. New Brunswick, NJ: Rutgers University Press.

Firebaugh, G. (1999). Empirics of world income inequality. American Journal of Sociology, 104(6), 1597-1630. https://doi.org/10.1086/210218

Fitzgerald, S. T., \& Glass, J. (2008). Can early family formation explain the lower educational attainment of U.S. conservative Protestants? Sociological Spectrum, 28(5), 556-577. https://doi.org/10.1080/ 02732170802206203

Fitzgerald, S. T., \& Glass, J. L. (2014). Conservative Protestants, normative pathways, and adult attainment. In L. A. Keister \& D. E. Sherkat (Eds.), Religion and inequality in America: Research and theory on religion's role in stratification (pp. 97-118). New York, NY: Cambridge University Press.

Fryer, R. G., Jr., \& Levitt, S. D. (2004). Understanding the black-white test score gap in the first two years of school. Review of Economics \& Statistics, 86(2), 447464. https://doi.org/10.1162/003465304323031049

Glass, J., \& Jacobs, J. (2005). Childhood religious conservatism and adult attainment among black and white women. Social Forces, 84(1), 555-579. https:// doi.org/10.1353/sof.2005.0098

Graf, N., Brown, A., \& Patten, E. (2017). The narrowing, but persistent, gender gap in pay. Pew Research Center. Retrieved November 5, 2017, from www.pew research.org/fact-tank/2017/04/03/gender-pay-gapfacts

Greeley, A. M. (1972). The denominational society: A sociological approach to religion in America. Glenview, IL: Scott, Foresman and Company.

Greeley, A. M. (1978). American Catholic: A social portrait. New York, NY: Basic Books.

Greeley, A. M., \& Hout, M. (2006). The truth about Conservative Christians: What they think and what they believe. Chicago, IL: University of Chicago Press.

Haug, M. R. (1977). Measurement in social stratification. Annual Review of Sociology, 3(1), 51-77. https:// doi.org/10.1146/annurev.so.03.080177.000411

Hedges, L. V., \& Nowell, A. (1999). Changes in the blackwhite gap in achievement test scores. Sociology of Education, 72(2), 111-135.

Hout, M., \& Fischer, C. S. (2002). Why more Americans have no religious preference: Politics and generations. American Sociological Review, 69(2), 165-190.

Hout, M., \& Fischer, C. S. (2014). Explaining why more americans have no religious preference: political backlash and generational succession, 1987-2012. Sociological Science, 1(October), 423-447. https://doi.org/10.15195/v1.a24

Hout, M., Smith, T. W., \& Marsden, P. V. (2016). Prestige and socioeconomic scores for the 2010 Census codes. (GSS Methodological Report no. 124). Chicago, IL: National Opinion Research Center. 
Hout, M., \& Wilde, M. J. (2004). The denominational society of the USA: A reappraisal. In A. Crockett \& R. O'Leary (Eds.), Patterns and processes of religious change in modern industrial societies: Europe and the United States (pp. 51-80). Lewiston, NY: Edwin Mellen Press.

Kao, G., \& Thompson, J. S. (2003). Racial and ethnic stratification in educational achievement and attainment. Annual Review of Sociology, 29(1), 417-442. https://doi.org/10.1146/annurev.soc.29. 010202.100019

Keister, L. A. (2003). Religion and wealth: The role of religious affiliation and participation in early adult asset accumulation. Social Forces, 82(1), 175-207.

Keister, L. A. (2007). Upward wealth mobility: Exploring the Roman Catholic advantage. Social Forces, 85(3), 1195-1225.

Keister, L. A. (2008). Conservative Protestants and wealth: How religion perpetuates asset poverty. American Journal of Sociology, 113(5), 1237-1271. https://doi.org/10.1086/525506

Keister, L. A. (2011). Religion and attainment. Sociological Focus; Abingdon, 44(4), 354-383.

Keister, L. A. (2012). Religion and wealth across generations. In L. A. Keister, J. Mccarthy, \& R. Finke (Eds.), Religion, work and inequality (Vol. 23, pp. 131-150). Bradford: Emerald Group Publishing Limited. https:// doi.org/10.1108/S0277-2833(2012)0000023009

Keister, L. A., \& Borelli, E. P. (2014). Religion and wealth mobility: The case of American Latinos. In L. A. Keister \& D. Sherkat (Eds.), Religion and inequality in America: Research and theory on religion's role in stratification (pp. 119-145). New York, NY: Cambridge University Press.

Keister, L. A., \& Sherkat, D. E. (2014). Introduction. In L. A. Keister \& D. Sherkat (Eds.), Religion and inequality in America: Research and theory on religion's role in stratification (pp. 1-21). New York, NY: Cambridge University Press.

Lehrer, E. (2004). Religiosity as a determinant of educational attainment: The case of Conservative Protestant women in the United States. Review of Economics of the Household, 2(2), 203-219. https:// doi.org/10.1023/B:REHO.0000031614.84035.8e

Lehrer, E., \& Chen, Y. (2014). The labor market behavior of married women with young children in the United States: Have differences by religion disappeared? In L. A. Keister \& D. Sherkat (Eds.), Religion and inequality in America: Research and theory on religion's role in stratification (pp. 146-169). New York, NY: Cambridge University Press.

Massengill, R. P. (2008). Educational attainment and cohort change among Conservative Protestants, 1972-2004. Journal for the Scientific Study of Religion, 47(4), 545-562. https://doi.org/10.1111/j.1468-5906.2008.00426.x

Massengill, R. P. (2014). Nona filiation and socioeconomic status: Differences in education and income between atheist and agnostics and "nothing in particular"s. In L. A. Keister \& D. Sherkat (Eds.), Religion and inequality in America: Research and theory on religion's role in stratification (pp. 31-51). New York, NY: Cambridge University Press.

McCall, L. (2001). Complex inequality: Gender, class and race in the new economy (1st edition). New York, NY: Routledge.

McConkey, D. (2001). Whither Hunter's culture war? Shifts in Evangelical morality, 1988-1998. Sociology of Religion, 62(2), 149-174. https://doi.org/ $10.2307 / 3712453$

Niebhur, R. H. (1929). The social sources of denominationalism. New York, NY: H. Holt and Company.

NORC at the University of Chicago. (2016). About the GSS. The General Social Survey. Retrieved from http://gss.norc.org/About-The-GSS

Orsi, R. A. (2002). The Madonna of 115th street: Faith and community in Italian Harlem. New Haven, CT; London: Yale University Press.

Pew Research Center. (2015). Religious landscape study. Pew Research. Retrieved from http://www. pewforum.org/religious-landscape-study

Pope, L. (1948). Religion and the class structure. Annals of the American Academy of Political and Social Science, 256(1), 84-91.

Proctor, B. D., Semega, J. L., \& Kollar, M. A. (2016). Income and poverty in the United States: 2015. Washington, DC: U.S. Census Bureau.

Pyle, R. E. (2006). Trends in religious stratification: Have religious group socioeconomic distinctions declined in recent decades? Sociology of Religion, 67(1), 61-79.

Pyle, R. E., \& Davidson, J. D. (2012). Religious stratification in america. In L. A. Keister, J. Mccarthy, \& R. Finke (Eds.), Religion, work and inequality (Vol. 23, pp. 3-25). Bradford: Emerald Group Publishing Limited. https://doi.org/10.1108/S0277-2833 (2012)0000023004

Pyle, R. E., \& Davidson, J. D. (2014). Social reproduction and religious stratification. In L. A. Keister \& D. E. Sherkat (Eds.), Religion and inequality in America (pp. 195-218). New York, NY: Cambridge University Press.

Read, J. G., \& Eagle, D. E. (2014). Intersectionality and identity: An exploration of Arab American women. In L. A. Keister \& D. E. Sherkat (Eds.), Religion and inequality in America: Research and theory on religion's role in stratification (pp. 52-74). New York, NY: Cambridge University Press.

Reimer, S. (2007). Class and congregations: Class and religious affiliation at the congregational level of analysis. Journal for the Scientific Study of Religion, 46(4), 583-594. https://doi.org/10.1111/j.14685906.2007.00379.x

Scheitle, C. P., \& Smith, B. G. (2012). Religious affiliation, college degree attainment, and religious switching. In L. A. Keister, J. Mccarthy, \& R. Finke (Eds.), Religion, work and inequality (Vol. 23, pp. 205-226). 
Bradford: Emerald Group Publishing Limited. https:// doi.org/10.1108/S0277-2833(2012)0000023012

Schwadel, P. (2009). Neighbors in the Pews: Social status diversity in religious congregations. Interdisciplinary Journal of Research on Religion, 5(2009).

Schwadel, P. (2011). The effects of education on Americans' religious practices, beliefs, and affiliations. Review of Religious Research, 53(2), 161-182. https://doi.org/10.1007/s13644-011-0007-4

Schwadel, P. (2016). Social class. In D. Yamane (Ed.), Handbook of religion and sociology (pp. 345-371). Berlin: Springer.

Shelton, J., \& Cobb, R. J. (2017). Black RelTrad: The measure for testing religious diversity and commonality among African Americans. Journal for the Scientific Study of Religion, 22(2), 222.

Sherkat, D. E. (1991). Leaving the faith: Testing theories of religious switching using survival models. Social Science Research, 20(2), 171-187. https://doi.org/ 10.1016/0049-089X(91)90015-U

Sherkat, D. E. (2010). Religion and verbal ability. Social Science Research, 39(1), 2-13. https://doi.org/ 10.1016/j.ssresearch.2009.05.007

Sherkat, D. E. (2011). Religion and scientific literacy in the United States. Social Science Quarterly, 92(5), 1134-1150. https://doi.org/10.1111/j.15406237.2011.00811.x

Sherkat, D. E. (2012). Religion and the American occupational structure. In L. A. Keister, J. A. Mccarthy, \& R. Finke (Eds.), Religion, work and inequality (Vol. 23, pp. 75-102). Bradford: Emerald Group Publishing Limited. Retrieved from http://proxy.library.upenn. edu:2295/doi/abs/10.1108/S0277-2833\%282012\%2 90000023007

Sherkat, D. E. (2014). Changing faith: The dynamics and consequences of Americans' shifting religious identities. New York, NY: NYU Press.

Shi, A. F., Massengill, R. P., \& Boddie, S. C. (2012). Did the religious group socioeconomic ranking change leading into the great recession? In L. A. Keister, J. A. Mccarthy, \& R. Finke (Eds.), Religion, work and inequality (Vol. 23, pp. 27-47). Bradford: Emerald Group Publishing Limited. https://doi.org/10.1108/S02772833(2012)0000023005

Smith, C., \& Faris, R. (2005). Socioeconomic inequality in the American religious system: An update and assessment. Journal for the Scientific Study of Religion, 44(1), 95-104.

Snyder, T. D., \& Dillow, S. A. (2015). Digest of education statistics: 2013. Washington, DC: National Center for Education Statistics Institute of Education Sciences, U.S. Department of Education. Retrieved from http://nces.ed.gov/pubs2015/2015011.pdf

Solt, F. (2014). Reversing the arrow? Economic inequality's effect on religiosity. In L. A. Keister \& D. E. Sherkat (Eds.), Religion and Inequality in America: Research and Theory on Religion's Role in Stratification (pp. 337-353). New York, NY: Cambridge University Press.

Steensland, B., Park, J. Z., Regnerus, M. D., Robinson, L. D., Wilcox, W. B., \& Woodberry, R. D. (2000). The measure of American religion: Toward improving the state of the art. Social Forces, 79(1), 291-318.

Stetzer, E., \& Burge, R. P. (2016). Reltrad Coding Problems and a New Repository. Politics and Religion, 9(1), 187-190. https://doi.org/10.1017/ S1755048315000929

Tilly, C. (1999). Durable inequality (Revised edition). Berkeley, CA: University of California Press.

Weber, M. (2003). The Protestant ethic and the spirit of capitalism. Mineola, NY: Dover Publications.

Wilde, M. J. (2017). Complex religion: Interrogating assumptions of independence in the study of religion. Sociology of Religion.

Wilde, M. J., \& Danielsen, S. (2014). Fewer and better children: Race, class, religion, and birth control reform in America. American Journal of Sociology, 119(6), 1710-1760. https://doi.org/10.1086/674007

Wilde, M. J., \& Glassman, L. (2016). How complex religion can help us understand politics in America. Annual Review of Sociology, 42(1). https://doi.org/ 10.1146/annurev-soc-081715-074420

Wilde, M. J., Pilgrim, H., \& Shen, W. (2017). Blackness as Primacy: The Continuing Significance of Race for Black American's Political Views. Presented at the Association for the Sociology of Religion and American Sociological Association, Montreal, Canada.

Wilde, M. J., \& Tevington, P. (2017). Complex religion: Toward a better understanding of the ways in which religion intersects with inequality. In R. A. Scott \& M. C. Buchmann (Eds.), Emerging trends in the social and behavioral sciences: An interdisciplinary, searchable, and linkable resource (pp. 1-14). Hoboken, NJ: John Wiley \& Sons, Inc. https://doi.org/ 10.1002/9781118900772.etrds0440

Wuthnow, R. (1988). The restructuring of American religion. Princeton, NJ: Princeton University Press.

Yancey, G., \& Kim, Y. J. (2008). Racial diversity, gender equality, and SES diversity in Christian congregations: Exploring the connections of racism, sexism, and classism in multiracial and nonmultiracial churches. Journal for the Scientific Study of Religion, 47(1), 103-111. 


\section{COGITATIO}

\section{About the Authors}

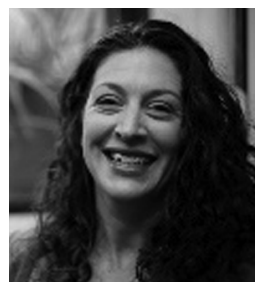

Melissa J. Wilde (Ph.D. in Sociology, 2002, from UC Berkeley) is an Associate Professor at the University of Pennsylvania. Most of her research has focused on religious change, including: the cultural and organizational factors behind Vatican II; the demographic factors that explain why American Protestantism has gone from being majority Mainline to majority conservative; and how race and class intersected with American religious groups to explain early stances on birth control. Lately, her research has become focused on how certain qualities of the American religious field, especially inequality, haven't changed, and how those enduring features of American religion can help us understand religious views of sex, poverty, and even politics today.

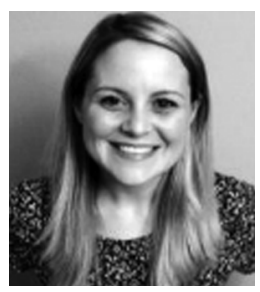

Patricia Tevington is a Doctoral Candidate in Sociology at the University of Pennsylvania. She received her bachelor's degree in Sociology from the College of New Jersey and her master's degree from the University of Pennsylvania. Her research interests include social class and inequality, sociology of religion, and sociology of the family. In particular, she studies how class and religious background affect the pathways of young people in their transition to adulthood.

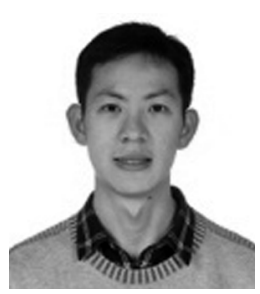

Wensong Shen is a PhD candidate in Sociology at the University of Pennsylvania. His research interests include social stratification, education, mental health, quantitative methods, and contemporary China. He is particularly interested in how education interacts with other social factors to shape social inequality. 
Annex

The Pew data confirms the findings laid out in our paper. Table A1 shows the descriptive statistics for our variables using the Pew 2014 Religious Landscape data. Please note that SEI is not available in the Pew data and is thus not included.

Table A1. Descriptives of variables, Pew data.

\begin{tabular}{|c|c|c|c|c|c|}
\hline & Mean / Proportion & SD & Min & Max & Observations \\
\hline Religious tradition (a) & & & & & 34848 \\
\hline Evangelical & 0.255 & & & & 8896 \\
\hline Mainline & 0.148 & & & & 5144 \\
\hline Black Protestant & 0.065 & & & & 2271 \\
\hline Catholic & 0.201 & & & & 7304 \\
\hline Jewish & 0.019 & & & & 650 \\
\hline Other Faith & 0.074 & & & & 2579 \\
\hline Nonaffiliated & 0.230 & & & & 8005 \\
\hline Education & 13.543 & 2.373 & 8 & 18 & 34868 \\
\hline Race & & & & & 34549 \\
\hline White & 0.662 & & & & 22862 \\
\hline Black & 0.116 & & & & 4002 \\
\hline Other & 0.223 & & & & 7686 \\
\hline Attendance & 3.561 & 1.635 & 1 & 6 & 34854 \\
\hline Age Range & 5.972 & 3.555 & 1 & 15 & 34345 \\
\hline Female & 0.515 & 0.500 & 0 & 1 & 35071 \\
\hline South & 0.371 & 0.483 & 0 & 1 & 35071 \\
\hline Urban & 0.373 & 0.484 & 0 & 1 & 35071 \\
\hline
\end{tabular}

Notes: Data from Pew 2014 Religious Landscape Study. All descriptives use the weight provided by Pew in their dataset. Age range starts from age 24 or below with 1 increase as an increment of 5 years. For simplicity, the observations for each category of RelTrad and race are rounded to integers; (a) The Pew Religious Landscape data is grouped into religious traditions with the same logic as Steensland et al. (2000), with a few exceptions. Notably, the Pew data breaks out some large religious groups to stand on their own in their classification scheme. In order to maintain consistency across the data, we recoded the Pew RelTrad variable as follows: Mormons, Orthodox Christians, Jehovah's Witness, Other Christians, Muslims, Buddhists, Hindus, and Other World Religions were coded as "Other Faith". The category of "don't know/refused" was dropped from the analysis.

Table A2 presents comparable crosstabulations for the religious traditions and mean income and proportion of members with bachelor's degrees using the 2014 Pew Religious Landscape data. The overall picture is the same: Jews and Mainline Protestants have a larger proportion of members with bachelor's degrees and higher mean income compared to Evangelicals and Black Protestants. One notable difference in the Pew data is that those of "Other Religions" have a higher proportion of members with bachelor's degrees than Mainline Protestants, which is reversed in the GSS data.

Table A2. Variations in class and demography by religious denominations, Pew data (ages 25-64).

\begin{tabular}{lrrr}
\hline & $N^{*}$ & Mean Income & Percent with BA or more \\
\hline Jewish & 361 & 120.77 & 68.38 \\
Mainline Protestant & 2940 & 78.41 & 36.60 \\
Other Religion & 1647 & 69.22 & 43.95 \\
No Religion & 5032 & 66.75 & 34.06 \\
Catholic & 4535 & 66.75 & 30.14 \\
Evangelical Protestant & 5594 & 61.68 & 24.03 \\
Black Protestant & 1493 & 41.07 & 16.57 \\
\hline
\end{tabular}

Note: ${ }^{*}$ These counts were generated using the provided weight and were rounded to the nearest integer. 
Table A3 uses religion to predict years of education via Ordinary Least Squares regression techniques with standard controls using the Pew Religious Landscape data. Compared to Mainline Protestants, Evangelicals, Black Protestants, and Catholics are less educated. As was the case in the GSS data set, Jews are significantly more educated than Mainline Protestants. There is no statistically significant difference found between Mainline Protestants and those of no religion or other religions using the Pew data.

Table A3. Effects of religion on years of education, Pew dataset.

\begin{tabular}{lc}
\hline & Education \\
\hline Mainline Protestant & Reference \\
Evangelical & $-0.798^{* * *}$ \\
& $(0.042)$ \\
Black Protestant & $-0.775^{* * *}$ \\
& $(0.085)$ \\
Catholic & $-0.529^{* * *}$ \\
& $(0.043)$ \\
Jewish & $1.025^{* * *}$ \\
& $(0.090)$ \\
Other Religion & $0.330^{* * *}$ \\
& $(0.058)$ \\
Nonaffiliated & 0.070 \\
& $(0.046)$ \\
\hline White & Reference \\
Black & $-0.753^{* * *}$ \\
& $(.062)$ \\
Other Race & $-1.100^{* * *}$ \\
& $(.036)$ \\
\hline Attendance & $0.121^{* * *}$ \\
& $(0.010)$ \\
Age & 0.000 \\
Female & $(.004)$ \\
& $-0.175^{* * *}$ \\
South & $(.026)$ \\
Urban & 0.029 \\
& $(.028)$ \\
$\mathrm{R}^{2}$ (\%) & $0.605^{* * *}$ \\
\hline
\end{tabular}

Notes: Standard errors in parentheses; ${ }^{*}<.05,{ }^{* *}<.01,{ }^{* *}<.001$. 
Finally, Table A4 demonstrates that religious groups are not evenly distributed across educational groups, using the Pew data set. Again, these predictions are dependent to some extent on the relative proportion of each group in the Pew Religious Landscape data (see Table A1 for the relative proportions). However, the point here is that these religious groups are not evenly distributed across socioeconomic groups. The overall picture displayed here is very similar to that found using the GSS dataset, with some gains and losses of statistical significance.

Table A4. The likelihood of religious group membership by education, Pew data.

\begin{tabular}{lllllll}
\hline & Evangelical & Black Protestant & Catholic & Jewish & Other Religion & Nonaffiliated \\
\hline Education & $0.868^{* * *}$ & $0.850^{* * *}$ & $0.914^{* * *}$ & $1.222^{* * *}$ & $1.056^{* * *}$ & $1.032^{* * *}$ \\
& $(0.006)$ & $(0.013)$ & $(0.007)$ & $(0.022)$ & $(0.011)$ & $(0.009)$ \\
White & Reference & Reference & Reference & Reference & Reference & Reference \\
Black & $1.758^{* * *}$ & $1,143.118^{* * *}$ & 1.138 & $0.415^{* * *}$ & $3.486^{* * *}$ & $4.674^{* * *}$ \\
& $(0.172)$ & $(203.604)$ & $(0.129)$ & $(0.138)$ & $(0.404)$ & $(0.493)$ \\
Other Race & $1.552^{* * *}$ & $14.026^{* * *}$ & $3.803^{* * *}$ & $0.621^{* * *}$ & $3.697^{* * *}$ & $2.112^{* * *}$ \\
& $(0.092)$ & $(2.829)$ & $(0.214)$ & $(0.102)$ & $(0.252)$ & $(0.132)$ \\
Attendance & $1.463^{* * *}$ & $1.180^{* * *}$ & $1.102^{* * *}$ & $0.788^{* * *}$ & $1.061^{* * *}$ & $0.373^{* * *}$ \\
& $(0.018)$ & $(0.033)$ & $(0.014)$ & $(0.021)$ & $(0.018)$ & $(0.006)$ \\
Age & $0.941 * * *$ & 0.988 & $0.982^{* * *}$ & 0.994 & $0.891^{* * *}$ & $0.839 * * *$ \\
& $(0.005)$ & $(0.011)$ & $(0.005)$ & $(0.011)$ & $(0.006)$ & $(0.005)$ \\
Year & $0.882^{* * *}$ & 0.989 & $0.897^{* * *}$ & 0.886 & $0.801^{* * *}$ & $0.697^{* * *}$ \\
& $(0.032)$ & $(0.074)$ & $(0.033)$ & $(0.068)$ & $(0.039)$ & $(0.028)$ \\
Female & $1.426 * * *$ & $1.275^{* * *}$ & $0.608^{* * *}$ & $0.727^{* * *}$ & $0.600^{* * *}$ & $0.751^{* * *}$ \\
South & $(0.052)$ & $(0.099)$ & $(0.024)$ & $(0.062)$ & $(0.032)$ & $(0.032)$ \\
& $0.864 * * *$ & $0.865 *$ & $1.744^{* * *}$ & $5.304 * * *$ & $1.177^{* * *}$ & $1.188^{* * *}$ \\
& $(0.035)$ & $(0.068)$ & $(0.069)$ & $(0.441)$ & $(0.062)$ & $(0.051)$ \\
\hline
\end{tabular}

Notes: Number of observations is 33531; pseudo R-squared is .2226; the reference category of religion is Mainline Protestant; standard errors in parentheses; ${ }^{*}<.05, * *<.01, * * *<.001$.

\section{References}

Steensland, B., Park, J. Z., Regnerus, M. D., Robinson, L. D., Wilcox, W. B., \& Woodberry, R. D. (2000). The measure of American religion: Toward improving the state of the art. Social Forces, 79(1), 291-318. 